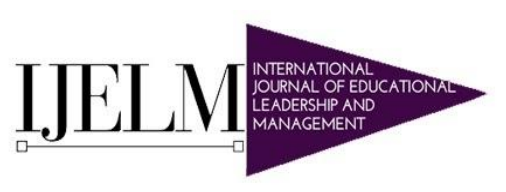

Hipatia Press

www.hipatiapress.com

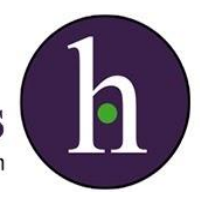

Instructions for authors, subscriptions and further details:

http://ijelm.hipatiapress.com

\title{
The Problems of School Administrators Scale
}

Kivanc Bozkus ${ }^{1}$

1) Artvin Coruh University, Turkey

Date of publication: January $16^{\text {th }}, 2022$

Edition period: January 2021 - July 2021

To cite this article: Bozkus, K. (2022). The Problems of School Administrators Scale. International Journal of Educational Leadership and Management. 10 (1), doi: 10.17583/ijelm.2022.7069

To link this article: http://dx.doi.org/10.17583/ijelm.2022.7069

\section{PLEASE SCROLL DOWN FOR ARTICLE}

The terms and conditions of use are related to the Open Journal System and to Creative Commons Attribution License (CCAL). 


\section{The Problems of School Administrators Scale}

Kivanc Bozkus

Artvin Coruh University

Turkey

\section{Abstract}

This study aims to develop a standardized data collection tool to identify the problems of school administrators. In the research conducted with the survey design, data were collected from 709 school administrators to develop the problems of school administrators scale. In this study, a theoretical framework was created according to the findings of the relevant studies and the scale of determining the problems of school administrators was developed. Exploratory and confirmatory factor analyses were done. According to the results, the problems of school administrators scale is a valid and reliable data collection tool that consists of 44 items and 8 dimensions. The scale can determine the problems of school administrators related to workload, personal rights, school administration, school climate, respect, education system, organizational commitment, and violence. With the Problems of School Administrators Scale, the level of problems can be determined, and necessary measures can be taken. If the scale can be applied in different regions at the same time, comparisons between regions can be made and attempts can be made to ensure equal opportunity

Keywords: workload, personal rights, school climate, respect, organizational commitment 


\section{La escala de problemas de los administradores escolares}

Kivanc Bozkus

Artvin Coruh University

Turkey

\section{Resumen}

Este estudio tiene como objetivo desarrollar una herramienta de recopilación de datos estandarizada para identificar los problemas de los administradores escolares. En la investigación realizada con el diseño de la encuesta, se recolectaron datos de 709 administradores escolares para desarrollar los problemas de escala de administradores escolares. En este estudio se creó un marco teórico de acuerdo con los hallazgos de los estudios relevantes y se desarrolló la escala de determinación de los problemas de los administradores escolares. Se realizaron análisis factoriales exploratorios y confirmatorios. Según los resultados, la escala de problemas de administradores escolares es una herramienta de recolección de datos válida y confiable que consta de 44 ítems y 8 dimensiones. La escala puede determinar los problemas de los administradores escolares relacionados con la carga de trabajo, los derechos personales, la administración escolar, el clima escolar, el respeto, el sistema educativo, el compromiso organizacional y la violencia. Con la Escala de Problemas de Administradores Escolares, se puede determinar el nivel de problemas y se pueden tomar las medidas necesarias. Si la escala se puede aplicar en diferentes regiones al mismo tiempo, se pueden hacer comparaciones entre regiones y se pueden hacer intentos para garantizar la igualdad de oportunidades.

Palabras clave: carga de trabajo, derechos personales, clima escolar, respeto, compromiso organizacional 
chool success is closely related to its administrators. The goals and methods determined by the manager for success also affect the other employees of the organization. Many factors related to success, such as the formation of competition between teachers and students on success, the discovery of individual talents, the design of the most appropriate educational processes for students, and the creation of classes, are shaped by the decisions of school administrators. Also, the ability of administrators to establish relationships with students, teachers and the environment means that the school turns into an institution that allows students to develop socially as well as academically. The school, which is in contact with the society, determines the needs and values of the society better and accurately by the teachers, thus creating an educational institution aimed at raising individuals suitable for the needs of the society. Effective management is required for this.

Many problems are encountered in ensuring effective management. When the literature is examined, it is stated that school administrators have problems related to workload, personal rights, school management, school climate, respect, education system, organizational commitment, and being exposed to violence. However, it can be said that related studies focus on one or a few problems and are mostly based on qualitative data that cannot be generalized. A standardized scale is needed to examine all problems at the same time, to quantify their degrees, and to reach generalizable results. This study aims to develop a standardized data collection tool to identify the problems of school administrators. In this study, a theoretical framework was created according to the findings of the relevant studies (Figure 1). Later, the scale of determining the problems of school administrators was developed to determine the problem areas related to workload, personal rights, school management, school climate, respect, education system, organizational commitment, and violence. In the following sections of the study, the findings of the researches that are the basis of the theoretical framework are presented according to the problem areas and the development steps of the scale are explained. 


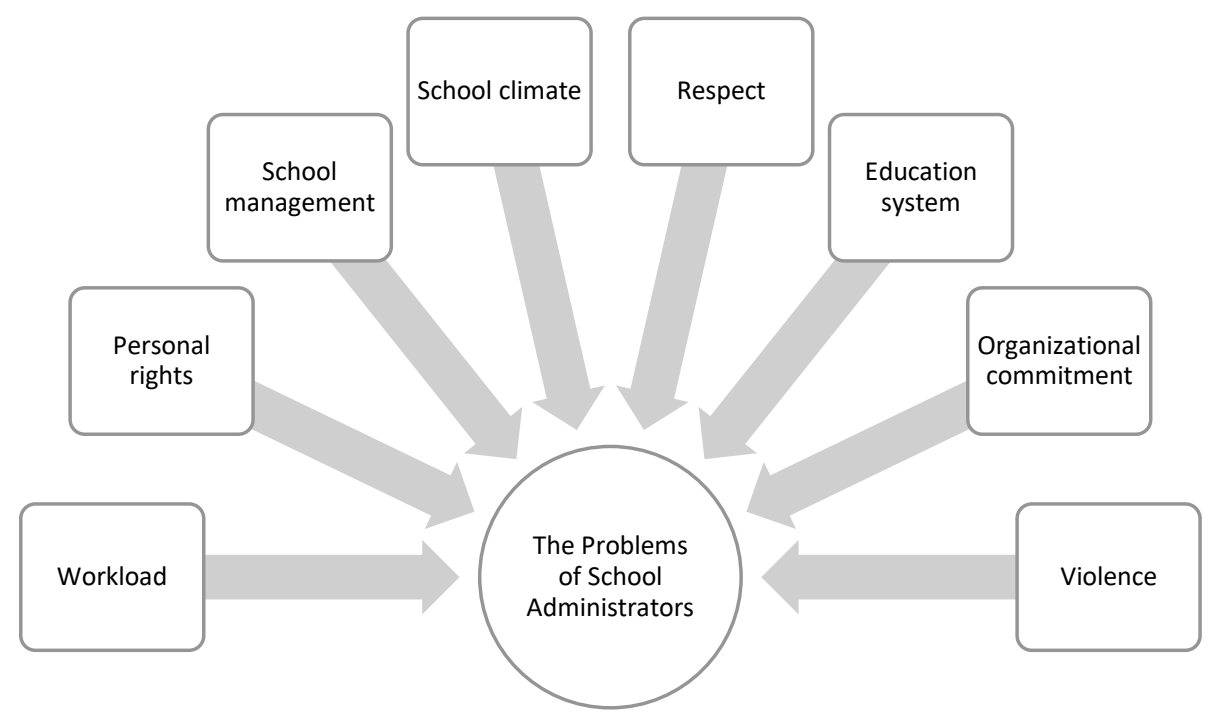

Figure 1. The research framework (generated by the author)

\section{Workload}

Since school administrators have more responsibilities, their workload is high. School administrators have so many responsibilities that new administrators are shocked (Spillane \& Lee, 2014). School administrators have duties such as ensuring the functioning of schools in line with the objectives, creating environments that will develop students physically, psychologically, and socially, ensure coordination of teachers, ensure building security, solve school needs within the budget, and establish communication between the school and the family. Many processes carried out by separate departments in other organizations are entirely under the responsibility of administrators in schools. Şahin (2011) states that school administrators experience stress arising from workload even when they are most successful, and they often have to spend time outside of their shifts to overcome this stress. So, the administrators try to finish their jobs by staying at school too 
much or by taking work to their homes. Of course, this situation causes them to strain both mentally and physically, and to not spare enough time for family and social life (Şahin, 2011). Because school administrators state that in their absence, the administrative processes in the school are interrupted (Ok, 2006). School administrators have high bureaucratic workloads (Çınkır, 2010; Günbay1 \& Akcan, 2013; Keser \& Gedikoğlu, 2008; Ural, 2002). Therefore, the workload causes administrators to break away from the teaching profession and not to spare time for family and friends (Köse \& Uzun, 2017). Administrators should be well-equipped, open to innovation, and have high communication skills. The negativities felt by school administrators with these qualifications may decrease.

\section{Personal Rights}

Despite their excessive workload, school administrators do not have the personal rights they deserve. Administrators have personal problems such as career opportunities, accommodation, retirement age, maternity leaves, and nursery (Acar \& Kitapç1, 2008; Gökdemirel, Bozkurt, Gökçay \& Bulut, 2008; Kay1kç1, 2008; Şahin, 2008; Uygun, 2005; Y1lmaz, Bozkurt \& İzci, 2008). Personal rights, including salaries of school administrators are far behind their counterparts (Göker \& Gündüz, 2017; Gündüz \& Can, 2011). Considering the responsibilities, duties, and authorities taken by school administrators, it can be thought that their income should be high. However, it can be said that administrators do not earn much compared to teachers, so they are exposed to injustice. School administration as an additional task of teaching is seen as the main source of this injustice (Akbaşl1 \& Balıkç1, 2013). At this point, the highest expectations of administrators from unions are in the dimension of personal rights (Sarpkaya, 2006). However, educators do not know their personal rights sufficiently and administrators act against the personal rights of teachers (Cereci, 2009; Erdem, 2010).

\section{School Management}

There are also many problems in the field of school management. School administrators experience problems due to economic inadequacies, unwanted student behavior, teachers, and physical conditions (Demir, 2016). 
Bureaucracy, shortage of resources, and poverty are the problems that managers complain about most (Sincar, 2013). In school management, student and technical problems create short-term problems, personnel, and parentsoriented problems are medium-term, organizational structure and policybased problems create long-term problems (Döş, Sağır, \& Çetin, 2015). The infrastructure of the school, its stakeholders, education policies, management, and financial problems are the problems that administrators care about most (Karaköse, Yirci, \& Kocabaş, 2014). The influx of immigrants in recent years in Turkey has affected the school management. School administrators state that they mostly experience communication, adaptation, absenteeism, psychological and financial problems regarding Syrian immigrant students (Toker Gökçe \& Acar, 2018). Another problem faced by school administrators is the physical conditions of the school and what level of education the school provides. Administrators stated that physical conditions are insufficient in most of the schools (Pamuk \& Kiraz, 2016). Old schools have financial and planning problems. No matter how well educated they are, school administrators may not have the skills to identify problems related to financial planning and physical conditions (Balyer, 2013). There are also problems in strategic planning (Arslan \& Küçüker, 2016). School administrators have a role in coping with inadequate teachers (Wragg, Haynes, Wragg, \& Chamberlin, 1999). Administrators stated that teachers who have insufficient professional knowledge, and who tend to cause problems due to their characteristics cause more problems than others (Erdoğan \& Demirkasımoğlu, 2016).

\section{School Climate}

School administrators also encounter problems related to the school climate. It is also stated in the literature that many problems related to school climate are experienced in schools (Taşdan, Tösten, Bulut, \& Karakaya, 2013). It has been determined that school administrators have problems in communication with parents, teacher qualification and rotation, physical and financial opportunities (Polat \& Arslan, 2017). The harsh attitudes of some administrators can cause negative reactions in students, teachers, employees, and parents. In addition to the "I know the best, I have the authority" and 
similar approaches, the indecisive and inconsistent behaviors of some administrators affect the whole school climate negatively (Ok, 2006). Administrators stated that they had problems in school-family relationships (Özer, Demirtaş, \& Ateş, 2015; Porsuk \& Kunt, 2012). Monitoring the appropriateness of school-family unity and other school activities, understanding the situation of families, and obtaining their approval are among the activities of administrators (Çalışkan \& Ay1k, 2015). Although the parent-teacher association is a bridge between school and parents, the attitude of school administrators has a very important role in the effectiveness of this communication. Administrators state that students have disciplinary problems due to their families' attitudes (Sadık \& Öztürk, 2018). School climate predicts the effectiveness of the school (Şenel \& Buluç, 2016). Therefore, creating a positive climate should be among the priorities of school administrators. Considering that there is a relationship between school climate and leadership (Şentürk \& Sağnak, 2012), problems in school climate can be overcome with the leadership of school administrators. School administrators stated that they should create a healthy school climate by solving problems themselves, taking measures to prevent problems from occurring, and preventing stress (Turan, Y1ldırım, \& Aydoğdu, 2012). Communication problems within the organization need to be easily identified and solved, staff should fulfill their duties effectively, and the school should have a cleaner environment (Babaoğlan, Nalbant, \& Çelik, 2017).

Communication requires the establishment of a correct network and the correct transmission of messages along with leadership skills (Çalışkan \& Ay1k, 2015). Communication is important not only for socializing but also for the correct understanding of problems and on-site intervention. It should not be forgotten that guidance services are also provided in schools for many reasons such as discovering students' abilities and supporting their psychological development. In cases where counseling service is not sufficient, many problems such as violence, low achievement, and bullying can easily arise at school. For this reason, school administrators have duties to control and motivate psychological development and counselling services (Apaydın \& Çakır, 2016). 


\section{Respect}

The respect of their ideas and the way others implement their decisions are closely related to the leadership skills of managers. Leaders are naturally people who are respected and followed. Teachers state that leadership of school administrators is one of the most important factors affecting the success of education (Babaoğlan, Nalbant, \& Çelik, 2017). If school administrators, teachers, and other school staff are respected by students, parents, and society, their self-confidence increases, and motivation can be provided within the organization (Çiçek Sağlam \& Emirbey, 2017). Appreciation and respect are the external factors that motivate school administrators the most (Y1ldirim, 2011). School administrators attach importance to respect (Aladağ \& Akyol, 2017). Administrators and teachers see respect as an important element of school culture (Aslan, Özer, \& Bakir, 2009). Teachers expect school administrators to create an environment based on respect (Aslanargun, 2015; Özel, 2014). However, motivational ways such as salary, promotion, authorization, participation in decision making, job enrichment cannot be provided by school administrators (Çiçek Sağlam \& Emirbey, 2017). Failure of school administrators to successfully realize the factors that will increase teachers' motivation may decrease the rate of respect and compliance of other employees towards themselves. It should not be forgotten that the attitudes and behaviors of those who carry out this duty also affect determining the respect and love felt towards school administrators. Attitudes and behaviors following ethical and moral rules make it possible for school administrators to be accepted, included in social relations, and respected within the society and organization, as is the case with all employees. For this reason, an educational administrator is expected to understand and apply professional ethics rules, as well as to understand the society and to analyze their value judgments. This situation can turn into a source of stress as well as the workload of managers (Argon, Çelik-Y1lmaz, \& İsmetoğlu, 2017). 


\section{Education system}

It has been determined in studies that school administrators have problems with the education system (Aslanargun \& Bozkurt, 2012; Cerit, Akgün, Y1ld1z, \& Soysal, 2014; Demirtaş, Üstüner, \& Özer, 2007; Ekinci, 2010). Demirtaş, Üstüner, and Özer (2007) underline that the problems faced by school administrators may arise from changes between schools, students, and parents. The authors argue that the facilities of the schools, the educational and cultural structures of parents and students, their economic conditions, and many demographic and physical characteristics related to this should be evaluated separately for each school. The authors, who emphasize that a school will have problems within the scope of its possibilities and that financial problems will be experienced, and that the expectations of parents and students from education and their participation in the school can also have an effect on creating and managing the system (Demirtaş, Üstüner, \& Özer, 2007).

School administrators do not have the goal of increasing profitability. Schools are not institutions that can finance themselves. School principals must complete the shortcomings and create a healthy education environment. Schools must have economic opportunities for the efficiency of education and training, the implementation of innovations, and achieving goals. Many details such as application areas, educational materials, cleaning, and environmental planning have to be used to support the mental and physical development of students (Yunas, 2014). At this point, school administrators are expected to identify deficiencies and needs, rank priorities, to make the right purchases, and to allocate the budget according to the needs. It is also essential to be transparent and ready to be accountable at all times. School administrators usually have to deal with all of them at the same time, although each of them requires separate training and experience (Mpolokeng, 2011; Wise, 2015). Administrators state that they are experiencing serious economic difficulties in their schools as the funds given by the government are insufficient (Özer, Demirtaş \& Ateş, 2015; Tosun \& Filiz, 2017). It is stated that the demands for meeting the expenses of the schools are not fulfilled by the senior management (Altunay, 2017). The cooperation of schools with 
municipalities is also not sufficient to solve economic problems (Özdoğan Özbal, 2017).

School administrators' values affect their perception of problems and their management style (Law, Walker, \& Dimmock, 2003). Centralization in the education system prevents school administrators from seeing every problem and causes communication problems between teachers, parents, employees, students, and the school administrators. Moreover, this situation affects the job satisfaction of other individuals working in the school and causes the problems between the administrators and the employees. The statements made by the top administrators of the ministry also cause the school administrators to have problems (Akçadağ, 2013). Changing education policies, laws, and legal gaps can cause difficulties for managers in terms of appointment and relocation regulations (Balyer, 2013).

\section{Organizational commitment}

The problems faced by school administrators damage their organizational commitment. Due to the multiplicity of problems, managers are getting colder from the profession, and the willingness of managers to leave increases (Bayar, 2016). The positive social interaction, safety, human resources, school management style, and financial resources of the school ensure organizational commitment by affecting the attitudes of school administrators towards the profession and school (Liu \& Bellibaş, 2018). Only a few studies address the organizational commitment levels of administrators (Akar, 2014). While in most of these studies it was determined that school administrators had problems with organizational commitment (Akar, 2014; Bozdemir \& Yolcu, 2014; Çelikten \& Çanak, 2014; Nayir, 2013), it was determined that they did not experience any problems in one study (Aksanaklu \& İnand1, 2018). It is claimed that the efforts of school administrators to solve the problems they encounter are directly proportional to organizational commitment (Bozdemir \& Yolcu, 2014). School administrators' lack of organizational commitment may cause them not to make enough effort to solve problems in other areas. To increase the organizational commitment of school administrators, they should be supported, should work in a comfortable and peaceful environment, 
their ideas should be valued, their complaints should be listened to, and their success should be rewarded (Çelikten \& Çanak, 2014). If school administrators think they are cared, the organizational commitment of administrators may increase (Karaköse \& Bozgeyikli, 2012). On the contrary, mobbing, on the other hand, harms organizational commitment (Aküzüm \& Oral, 2015; Cemaloğlu, 2014).

There is a significant relationship between school administrators' personality traits and organizational commitment (Ayık, Savaş, \& Yücel, 2015; Shabahang \& Amani, 2016). School administrators' organizational commitment levels also determine the relationships between teachers and other employees within the organization. With the creation of an effective communication environment, all other school staff, students, and parents will participate in the education process, which may mean more successful results in the future (Babaoğlan, Nalbant, \& Çelik, 2017).

\section{Violence}

In schools, various factors such as the age of students, the education and economic status of their families, and the prevalence of domestic violence may have an effect on the frequency of violence from students by students, teachers, and even school administrators. When students feel under pressure or depending on their upbringing, they can be prone to violence and harm both themselves and their environment. At this point, school administrators have to take additional measures to prevent violence and bullying and also prevent them from being exposed to violence. The presence of violence is unacceptable in environments such as schools where education and training are carried out together (Hoşgörür \& Orhan, 2017). However, administrators state that they experience problems due to violence in their schools (Bayar, 2016). Although it is the administrators' responsibility to combat violence in the school (Bartsch \& Cheurprakobkit, 2002), what needs to be done to ensure school safety exceeds the authority of school administrators and falls under the authority of the top management (Yıldırım, Akan, \& Çiftçi, 2018).

School safety is an important variable for effective schools (Çobanoğlu \& Badavan, 2017). School administrators encounter disciplinary problems at a 
moderate level (Vatansever Bayraktar \& Kaya, 2017). The first step that school administrators must take to prevent violence is to enable mutual communication skills between teachers, students, and parents. However, managers who are caught in a busy workload, and other problems may not always have enough patience to accomplish this. This situation may also cause the principals to verbally or physically apply violence against others. It should not be forgotten that principals are likely to be both the victims and the perpetrators of violence (Tumwine, 2014).

\section{Method}

\section{Research design}

The research is in a survey design. With the survey design, the perceptions and attitudes of a large sample can be demonstrated with standard data collection tools with proven validity and reliability, and thus generalizable results can be obtained (Christensen, Johnson, \& Turner, 2013). When the data is collected at once, it is cross-sectional, and when it is collected multiple times over larger periods, longitudinal surveying is performed (Fraenkel, Wallen, \& Hyun, 2012, p.394). In this study, data were collected by crosssectional surveying.

\section{Participants}

All school administrators working in a city of Turkey in the spring term of 2018 were reached without taking a sample. Since the research employs online survey design, a sampling technique would reduce maximum participants. The city was chosen due to the high problems in its schools (Karacabey \& Boyac1, 2018). The Ministry of National Education sent an official letter to all schools and invited the administrators to participate in the research. A total of 751 administrators among 5624 school administrators working in the official primary, secondary and high schools in the city during the 2017-2018 academic year have volunteered. When the incorrectly filled forms were eliminated, the remaining 709 administrators were among the participants of the study. The statistics of the participants are presented in Table 1. 
Table 1. The statistics of the participants

\begin{tabular}{cccc}
\hline \multirow{2}{*}{ Factor } & Variable & $\begin{array}{c}\text { Frequency } \\
\text { (f) }\end{array}$ & $\begin{array}{c}\text { Percentage } \\
(\boldsymbol{\%})\end{array}$ \\
\hline \multirow{2}{*}{ Gender } & Male & 532 & 75.0 \\
& Female & 177 & 25.0 \\
\hline \multirow{4}{*}{ Administrato } & 0-2 years & 368 & 51.9 \\
r seniority & 3-5 years & 168 & 23.7 \\
& 6-8 years & 66 & 9.3 \\
& 9 years and above & 98 & 13.8 \\
& Undefined & 9 & 1.3 \\
\hline \multirow{3}{*}{ Educator } & 0-2 years & 106 & 15.0 \\
seniority & 3-5 years & 191 & 26.9 \\
& 6-8 years & 110 & 15.5 \\
& 9 years and above & 294 & 41.5 \\
Graduation & Undefined & 8 & 1.1 \\
\hline \multirow{2}{*}{ School size } & Bachelor's & 635 & 89.6 \\
& Graduate & 74 & 10.4 \\
\hline \multirow{2}{*}{ School type } & 12-499 & 351 & 49.5 \\
& 500-999 & 232 & 32.7 \\
& 1000 and above & 126 & 17.8 \\
\hline & Preschool & 29 & 4.1 \\
& Primary school & 300 & 42.3 \\
& High school & 219 & 30.9 \\
& & 161 & 22.7 \\
\hline
\end{tabular}

$532(75 \%)$ of the administrators are men and $177(25 \%)$ are women. Responses to management seniority vary between 0 and 32 years. Responses to the education seniority vary between 0 and 39 years. The answers are given to the number of students in the school also ranged from 12 to $3680.29(4.1 \%)$ of the administrators work in kindergarten, 300 (42.3\%) in primary school, $219(30.9 \%)$ in secondary school, $161(22.7 \%)$ in high school. A significant portion of the administrators are undergraduate $(n=635,89.6 \%)$ and a small portion are graduate $(\mathrm{n}=74,10.4 \%)$. 


\section{Data collection tool}

The data were collected using an online form. The form included questions about demographic variables and the scale for determining the problems of school administrators. In the scale developed by the researcher, 44 items with frequencies between $1=$ never and $5=$ always are included in 8 dimensions (Appendix). A draft form was created by writing 72 items according to the results of the literature review, especially the results of previous studies (Çınkır, 2010; Demirtaş, Üstüner \& Özer, 2007; Ekinci, 2010; Erol, 1995; Turan, Y1ldırım, \& Aydoğdu, 2012). Among these items, 22 items need to be reverse coded. The items contain statements regarding the problems that school administrators may encounter. For example, an item has the statement "I have to work on weekends". Therefore, it can be said that the higher the average of the responses given to the items, the more often the managers encountered the related problem.

\section{Collection of Data}

The data were collected using an online form. Compared to conventional paper forms, online forms can save cost and time, can be easily applied to large masses, and facilitate data analysis (Fan \& Yan, 2010; Selm \& Jankowski, 2006). Also, online forms can be regarded as equivalent to paper forms, as they do not affect research results (Huang, 2006).

\section{Analysis of Data}

Data were analyzed with $\mathrm{R}$, an open-source statistical programming language (Ihaka \& Gentleman, 1996). R has been widely used for the last 20 years (Field, Miles, \& Field, 2012). Experts create program packages to make certain analyzes with R (Beaujean, 2014). Exploratory factor analysis with the psych (Revelle, 2018) package included in the R library, confirmatory factor analysis with the lavaan (Rosseel, 2012) package, and mvn (Korkmaz, Göksülük \& Zarars1z, 2014) package were performed with multivariate normality assumption analysis. When the multivariate normality assumption is examined, it is found to be significant $(\mathrm{p}<.001)$ for the Doornik-Hansen 
(2008), Henze-Zirkler (1990), Mardia (1970, 1974) and Royston (1992) tests. Therefore, the Principal Axis Factoring (PAF) was used for the exploratory factor analysis (Strahan, 1999), and Diagonally Weighted Least Squares (DWLS) calculation was used for the confirmatory factor analysis (Mindrila, 2010).

\section{Results}

After collecting the data with the draft form applied to a group of 50 people in a pilot study, 8 items with low item-total correlations $(r<.35)$ were eliminated. Explanatory factor analysis was performed with PAF on the remaining 64 items and the data collected from 709 school administrators. The Kaiser-Meyer-Olkin value calculated for the adequacy of the data amount was found at the level of .86 and the Bartlett test was found to be statistically significant $(\mathrm{p}<.001)$. According to the parallel analysis technique, it was predicted that the scale could have 8 dimensions. Since significant $(p<.05)$ correlations were determined among the dimensions, the distribution of the items by the promax oblique rotation technique was used. Cronbach's alpha reliability coefficients of the sub-dimensions ranged from $\alpha=.65$ to $\alpha=.83$. It is accepted that the Cronbach alpha coefficient should be $\alpha=.65$ and above (Spector, 1992; Vaske, 2008). Revelle beta coefficient, which is the lowest limit of the splitting reliability, was found to be $=.76$, the upper limit Guttman lambda 4 coefficient was found to be $\lambda 4=.94$, and the average coefficient was $=.89$. The total variance that the scale can explain is $48 \%$. When the eightdimensional structure was tested with the confirmatory factor analysis based on DWLS calculation, good fit index values were determined $(\chi 2 / \mathrm{df}=1.72$, $\mathrm{p}<.001, \mathrm{AGFI}=.95, \mathrm{GFI}=.96, \mathrm{CFI}=.96, \mathrm{NFI}=.92, \mathrm{IFI}=.96, \mathrm{RFI}=.91$ RMSEA $=.03$, SRMR $=.05)$, and the construct validity was ensured by finding the factor structure compatible with the data (Hooper, Coughlan, \& Mullen, 2008). The factor loads of the items varied between .34 and .90 (Table 2). 
Table 2. Factor statistics

\begin{tabular}{lccccc}
\hline Dimensions & Items & Factor Load & $\boldsymbol{\alpha}$ & $\begin{array}{c}\text { Variance } \\
\%\end{array}$ & Mean \\
\hline Education system & 11 & $.34-.67$ & .76 & 7 & 3.78 \\
Workload & 7 & $.53-.77$ & .82 & 6 & 3.69 \\
Personal rights & 6 & $.43-.69$ & .74 & 5 & 3.29 \\
School climate & 6 & $.38-.59$ & .67 & 4 & 3.11 \\
School & 5 & $.41-.60$ & .65 & 4 & 1.97 \\
management & & $.69-.81$ & .83 & 5 & 2.08 \\
$\begin{array}{l}\text { Respect } \\
\text { Violence }\end{array}$ & 4 & $.58-.75$ & .74 & 4 & 1.57 \\
$\begin{array}{l}\text { Organizational } \\
\text { commitment }\end{array}$ & 3 & $.56-.90$ & .67 & 3 & 3.15 \\
\hline
\end{tabular}

The dimension that school administrators have the most problems with is the education system $(\mathrm{X}=3.78, \mathrm{Sd}=0.61)$. The dimension with the least problem is the dimension of experiencing violence $(\mathrm{X}=1.57, \mathrm{Sd}=0.80)$. According to the findings, it can be said that school administrators frequently experience problems related to the education system and workload. Sometimes problems may arise regarding personal rights, organizational commitment and school climate. School administrators rarely have problems with respect and school management. It can be said that the administrators have never been subjected to violence.

The correlations between the dimensions of the scale of determining the school administrators' problems were examined. The findings are presented in Table 3.

Table 3. Correlations between dimensions

\begin{tabular}{|c|c|c|c|c|c|c|c|}
\hline & Workload & $\begin{array}{l}\text { Personal } \\
\text { rights }\end{array}$ & $\begin{array}{l}\text { School } \\
\text { management }\end{array}$ & $\begin{array}{l}\text { School } \\
\text { climate }\end{array}$ & Respect & $\begin{array}{l}\text { Education } \\
\text { system }\end{array}$ & $\begin{array}{l}\text { Organizational } \\
\text { commitment }\end{array}$ \\
\hline Personal rights & $.33^{* *}$ & & & & & & \\
\hline $\begin{array}{l}\text { School } \\
\text { management }\end{array}$ & $.25^{* *}$ & $.29^{* *}$ & & & & & \\
\hline School climate & $.24^{* *}$ & $.37^{* *}$ & $.26^{* *}$ & & & & \\
\hline Respect & $.12^{*}$ & $.34^{* *}$ & $.39^{* *}$ & $.36^{* *}$ & & & \\
\hline $\begin{array}{l}\text { Education } \\
\text { system }\end{array}$ & $.38^{* *}$ & $.41^{* *}$ & $.31^{* *}$ & $.31^{* *}$ & $.17^{* *}$ & & \\
\hline $\begin{array}{l}\text { Organizational } \\
\text { commitment }\end{array}$ & $.26^{* *}$ & $.22^{* *}$ & $.24^{* *}$ & $.15^{* *}$ & $.20^{* *}$ & $.34^{* *}$ & \\
\hline Violence & $.29^{* *}$ & $.28^{* *}$ & $.46^{* *}$ & $.23^{* *}$ & $.29^{* *}$ & $.25^{* *}$ & $.16^{* *}$ \\
\hline
\end{tabular}


All of the correlations between dimensions are statistically significant and at a positive level. However, it can be said that the correlations are generally low. The correlations between dimensions are not too high or too low, indicating an acceptable factor structure. The workload dimension is mostly related to the education system and personal rights. Similarly, personal rights dimension is mostly related to the education system and school climate, the school management dimension is mostly related to violence and respect, the school climate dimension is mostly related to personal rights and respect, the respect dimension is mostly related to school management and climate, the education system dimension is mostly related to personal rights and workload, organizational commitment is mostly related to the education system and workload, and exposure to violence is mostly related to school management, workload, and respect.

\section{Conclusion}

In this study, it was determined that school administrators frequently experienced problems related to the education system. It has also been determined in previous studies that school administrators have problems with the education system (Aslanargun \& Bozkurt, 2012; Cerit, Akgün, Y1ld1z \& Soysal, 2014; Demirtaş, Üstüner \& Özer, 2007; Ekinci, 2010). Suggestions can be given based on the results of the research for the solution of the problems experienced by school administrators in the education system. Not mixing politics with education, not making frequent changes in the education system, increasing the quality of teachers, eliminating rote learning, arranging the appointment and relocation regulations in line with the views of the administrators, preventing ideological discrimination and favoritism, changing the criteria for selecting administrators, reducing the differences between the opportunities of the schools, ensuring academic success. It can be suggested that administrators be supported to cope with student behaviors and to adapt to immigrant students.

In the study, it was also determined that school administrators frequently had problems related to workload. It is also stated in previous studies that school administrators have a high bureaucratic workload (Çınkır, 2010; 
Günbay1 \& Akcan, 2013; Keser \& Gedikoğlu, 2008; Ural, 2002). Özdemir and Sezgin (2002) state that school administrators have many obligations regarding leadership. Thanks to their leadership skills, managers can make business planning and distribution of authority easier and faster. Leadership styles change approaches to planning, execution, decision making, distributing responsibility and so on. The authors imply that leadership skills are not sufficient to be successful in the field of school administration and to cope with the workload. Managers should be well-equipped, open to innovation, and have high communication skills. The negativities felt by school administrators with these qualifications can be reduced. The stress level of school administrators due to organizational factors may also increase (Ural, 2002). In schools, many factors such as insufficient cooperation, excessive workload, bureaucratic and financial obstacles, family-studentteacher-management mismatch reduce the ability of administrators to cope with stress (Madenoğlu, 2013). Regarding the workload dimension, it can be suggested to reduce the workload of school administrators, to provide adequate financing to schools, to provide managers with stress management support and to reduce paperwork.

Another result of the research is that school administrators sometimes have problems with their personal rights. It is stated in the literature that educators have problems with their personal rights (Günduiz \& Can, 2011). However, in a study, $70 \%$ of school administrators found their personal rights sufficient (Akbaşl1 \& Balıkç1, 2013). Considering the responsibilities, duties and authorities that school administrators take, it can be thought that their income should be higher. However, it can be said that administrators do not earn much compared to teachers, so they are unfairly treated. In order to improve personal rights, it can be suggested to increase the number of institutions representing school administrators, the Ministry and unions to observe the rights of school administrators, the regulation of the legislation to solve the problems, and the fairness of school inspections.

As a result of the research, it was determined that school administrators sometimes have problems with the school climate. It is also stated in the literature that school climate-related problems are experienced in schools 
(Taşdan, Tösten, Bulut \& Karakaya, 2013). It has been determined that school administrators have problems with communication with parents, teacher qualification and rotation, and physical and financial opportunities (Polat \& Arslan, 2017). Contrary to the results, in a study, it was determined that school administrators did not have any problems with the school climate (Demirtaş, Üstüner \& Özer, 2007). Regarding the school climate dimension, it can be suggested to increase the physical facilities of the schools, the school-family cooperation, the guidance service provided to the students, the importance given by the parents to the education and the students' desire to learn.

According to another result reached within the scope of the research, school administrators sometimes have problems with organizational commitment. It can be said that this situation generally agrees with the results of the studies dealing with the organizational commitment level of school administrators. Since organizational commitment studies in schools are mostly conducted with teachers, there are few studies on the organizational commitment level of administrators (Akar, 2014). It is recommended to take measures to increase the organizational commitment of school administrators.

Fortunately, school administrators rarely have problems with respect, school management and they had never been subjected to violence. Similar results were obtained in a previous study (Çetin \& Alpanık, 2012).

In this study, a standardized data collection tool to identify the problems of school administrators for the first time in Turkey was developed. Determining the School Administrators' Problems Scale is a valid and reliable data collection tool consisting of 44 items and 8 dimensions. The scale can determine the problems faced by school administrators regarding workload, personal rights, school administration, school climate, respect, education system, organizational commitment, and violence. Although these problem areas are determined by a comprehensive literature review, the total variance that the scale can explain remains at $48 \%$, indicating that there are more problems to be measured. Of course, the total variance explained may also vary according to the calculation method used. Nevertheless, data collection tools that can identify as many problems as possible should be developed through more comprehensive research in the future. Measuring organizational 
commitment with two items is another limitation. Future research must find ways to overcome these limitations. Since there is no similar scale, an equivalent form could not be used to test the criterion validity. This scale can be used as an equivalent form in future research. Developments in the education system may cause school administrators to encounter new problems. The increasing importance of issues such as inclusive education and global competence and changes in demographic structure due to immigrants may also reveal new problem areas. Therefore, the developed scale should be updated with new researches in the future. With the Problems of School Administrators Scale, the level of problems experienced can be determined and necessary measures can be taken. If the scale can be applied in different regions at the same time, comparisons between regions can be made and attempts can be made to ensure equal opportunity.

\section{Reference}

Acar, İ. A., \& Kitapçı, İ. (2008). Sosyal güvenliğin demografik boyutu: Türkiye'deki emeklilik sistemindeki değişim. Maliye Dergisi, 154, 77-98.

Akar, H. (2014). Okul yöneticilerinin örgütsel bağl1lıklarının incelenmesi. Sosyal Bilimler Dergisi, 4(8), 110-132.

Akbaşl1, S., \& Balıkçı, A. (2013). Okul yöneticisi ve öğretmen görüşlerine göre okul yöneticiliğinin meslekleşmesinin değerlendirilmesi. Mersin Üniversitesi Eğitim Fakültesi Dergisi, 9(2), 366-377.

Akçadağ, T. (2013). Okul yöneticilerinin bakış açllarıyla üst yönetimler: Sorunlar, çözümler, beklentiler, yansımalar. International Journal of Human Sciences, 10(2), 379-399.

Aksanaklu, P., \& İnandı, Y. (2018). Okul yöneticilerinin örgütsel bağl1lıkları ile tükenmişlik düzeyleri arasındaki ilişkinin incelenmesi. Mersin University Journal of the Faculty of Education, 14(3), 937-955.

Aküzüm, C., \& Oral, B. (2015). Yönetici ve öğretmen görüşleri açısından okullarda görülen en yaygın şiddet olayları, nedenleri ve çözüm önerileri. EKEV Akademi Dergisi, 19(61), 1-27. 
Aladağ, S., \& Akyol, B. (2017). The views of school administrators on the values education given in the schools: A case study. International Journal of Eurasia Social Sciences, 8(29), 1258-1274.

Altunay, E. (2017). Okul yöneticilerinin görüşleri doğrultusunda eğitim finansmanı politikaları: Sorunlar, nedenler ve çözümler. Bartın Üniversitesi Eğitim Fakültesi Dergisi, 6(2), 689-714.

Apaydın, S., \& Çakır, S. G. (2016). Okul yöneticilerinin PDR hizmetlerinin gerekliliği ve etkililiğine ilişkin algılarının bazı değişkenler açısından incelenmesi. In Ö. Demirel \& S. Dinçer (Eds.), Ĕgitim Bilimlerinde Yenilik ve Nitelik Arayışı (pp. 655-667). Ankara: Pegem.

Argon, T., Çelik-Yılmaz, D., \& İsmetoğlu, M. (2017). Okul yöneticilerinin meslek ahlakı davranışlarına yönelik öğretmen görüşleri. Eğitim ve Öğretim Araştırmaları Dergisi, 6(3), 210-221.

Arslan, G., \& Küçüker, E. (2016). Okul müdürlerinin planlama etkinlikleri ve stratejik planlamada karşılaşılan sorunlar. Kastamonu Education Journal, 24(2), 839-856.

Aslan, M., Özer, N., \& Bakır, A. A. (2009). Okul kültürüne ilişkin yönetici ve öğretmen görüşleri: Nitel bir araştırma. Ilköğretim Online, 8(1), 268-281.

Aslanargun, E. (2015). Teachers' expectations and school administration: Keys of better communication in schools. Eurasian Journal of Educational Research, 60, 17-34.

Aslanargun, E., \& Bozkurt, S. (2012). Okul müdürlerinin okul yönetiminde karşılaştı̆̆1 sorunlar. Gaziantep University Journal of Social Sciences, 11(2), 349-368.

Ayık, A., Savaş, M., \& Yücel, E. (2015). İlkokullarda görev yapan okul müdürlerinin genel öz yeterlik ile örgütsel bağlılık algıları arasındaki ilişkinin incelenmesi. Uşak Üniversitesi Sosyal Bilimler Dergisi, 8(2), 193-218.

Babaoğlan, E., Nalbant A., \& Çelik, E. (2017). Okul başarısına okul yöneticisinin etkisine ilişkin öğretmen görüşleri. Mehmet Akif Ersoy Üniversitesi Ĕ̆itim Fakültesi Dergisi, 43, 93-109. 
Balyer, A. (2013). Okul yöneticilerinin kariyer gelişim kararlarını etkileyen kurumsal ve kişisel faktörler. Türk Eğitim Bilimleri Dergisi, 11(1), $1-26$.

Bartsch, R. A., \& Cheurprakobkit, S. (2002). School problems and learning about crime and justice systems: principals' views. Educational Studies, 28(3), 275-285.

Bayar, A. (2016). Challenges facing principals in the first year at their schools. Universal Journal of Educational Research, 4(1), 192-199.

Beaujean, A. A. (2014). Latent variable modeling using R: A step-by-step guide. New York: Routledge.

Bozdemir, Y., \& Yolcu, H. (2014). Okul yöneticilerinin örgütsel adanmışlık düzeyleri ile problem çözme becerileri arasındaki ilişki. Ĕgitim Bilimleri Araştırmaları Dergisi, 4(2), 287-311.

Cemaloğlu, N. (2014). Examining relationships between school administrators' humor behaviors and teachers' mobbing experiences according to teacher perceptions. International Online Journal of Educational Sciences, 6(3), 570-580.

Cereci, C. (2009). Kamu ilk ve orta öğretim okullarında çalışan öğretmenlerin özlük haklarını bilme ve kullanma düzeyleri (Mersin ili Tarsus ilçesi örneği) (Unpublished Master's Thesis). Ankara Üniversitesi Eğitim Bilimleri Enstitüsü, Ankara.

Cerit, Y., Akgün, N., Yıldız, K., \& Soysal, M. R. (2014). Yeni eğitim sisteminin $(4+4+4)$ uygulanmasında yaşanan sorunlar ve çözüm önerileri (Bolu il örneği). Eğitim Bilimleri Araştırmalart Dergisi, 4(1), 59-82.

Christensen, L. B., Johnson, R. B., \& Turner, L. A. (2013). Research methods: Design and analysis (12. ed.). Boston: Pearson.

Çalışkan, N., \& Ayık, A. (2015). Okul aile birliği ve velilerle iletişim. Ahi Evran Üniversitesi Sosyal Bilimler Enstitüsü Dergisi, 1(2), 69-82.

Çelikten, M., \& Çanak, M. (2014). Okul yöneticilerinin örgütsel bağl1lıkları ile örgütsel sinizmleri arasındaki ilişki. OPUS Uluslararası Toplum Araştırmaları Dergisi, 4(6), 45-78.

Çetin, M., \& Alpanık, F. (2012). Yönetici, öğretmen ve öğrencilerin okul içi şiddet algısı ile motivasyon düzeyleri arasındaki ilişkinin incelenmesi. 
Marmara Üniversitesi Atatürk Eğitim Fakültesi Ĕ̆itim Bilimleri Dergisi, 35, 105-122.

Çınkır, Ş. (2010). İlköğretim okulu müdürlerinin sorunları: Sorun kaynakları ve destek stratejileri. Ilkögretim Online, 9(3), 1027-1036.

Çiçek Sağlam, A., \& Emirbey, A. R. (2017). Okul yöneticilerinin etik liderlik davranışları ile öğretmen motivasyonu arasındaki ilişki. Türk \& Íslam Dünyası Sosyal Araştırmalar Dergisi, 4(12), 92-104.

Çobanoğlu, F., \& Badavan, Y. (2017). Başarılı okulların anahtarı: Etkili okul değişkenleri. Pamukkale Üniversitesi Sosyal Bilimler Enstitüsü Dergisi, (26), 114-134.

Demir, M. K. (2016). Problems encountered by school principals: Unchanging facts of changing Turkey. The Anthropologist, 23(3), 629-640.

Demirtaş, H., Üstüner, M., \& Özer, N. (2007). Okul yönetiminde karşılaşılan sorunların öğrenci ve okul ile ilgili değişkenler açısından incelenmesi. Kuram ve Uygulamada Eğitim Yönetimi, 51, 421-455.

Doornik, J. A., \& Hansen, H. (2008). An omnibus test for univariate and multivariate normality. Oxford Bulletin of Economics and Statistics, 70, 927-939.

Döş, İ., Sağır, M., \& Çetin, R. B. (2015). Classsifying daily problems of school managers. Procedia-Social and Behavioral Sciences, 197, 2040-2045.

Ekinci, A. (2010). İlköğretim okullarında çalışan müdür ve öğretmenlerin mesleki sorunlarına ilişkin görüşleri. İlköğretim Online, 9(2), 734748.

Erdem, A. R. (2010). İlköğretim ve ortaöğretim öğretmenlerinin karşılaştığ1 özlük sorunları ve bu özlük sorunlarının performanslarına etkisi konusundaki görüşleri. Adnan Menderes Üniversitesi Ĕgitim Fakültesi Ĕgitim Bilimleri Dergisi, 1(1), 21-55.

Erdoğan, C., \& Demirkasımoğlu, N. (2016). Marginal teachers from the eyes of school principals: Concept, problems and management strategies. Journal of Education and Training Studies, 4(4), 77-92.

Erol, F. (1995). Okul müdürlerinin görevlerini başarmada karşılaştıkları engeller (Burdur ili örneği). Eğitim Yönetimi Dergisi, 1(1), 63-71. 
Fan, W. \& Yan, Z. (2010). Factors affecting response rates of the web survey: A systematic review. Computers in Human Behavior, 26, 132-139. Field, A., Miles, J., \& Field, Z. (2012). Discovering statistics using R. London: Sage.

Fraenkel, J. R., Wallen, N., \& Hyun, H. (2012). How to design and evaluate research in education (8. ed.). New York: McGraw-Hill.

Gökdemirel, S., Bozkurt, G., Gökçay, G., \& Bulut, A. (2008). Çalışan annelerin emzirme sürecinde yaşadıkları: Niteliksel bir çalışma. Çocuk Dergisi, 8(4), 221-234.

Göker, S. D., \& Gündüz, Y. (2017). Dünya ölçeğinde öğretmenlerin saygınlık statüsü ve özlük hakları. Milli Eğitim Dergisi, 213, 177-196.

Günbay1, İ., \& Akcan, F. (2013). İlköğretim kurumları yöneticilerinin yaşadıkları iş streslerine ilişkin görüşleri: Bir durum çalışması. Öğretmen Ĕ̆itimi ve Ĕgitimcileri Dergisi, 2(2), 195-224. Gündüz, Y., \& Can, E. (2011). Öğretmenlerin eğitim sistemi ve uygulamalarına ilişkin güncel sorunları algılama düzeylerinin incelenmesi. Türk Ë̆itim Bilimleri Dergisi, 9(4), 745-774.

Henze, N., \& Zirkler, B. (1990). A class of invariant consistent tests for multivariate normality. Communications in Statistics-Theory and Methods, 19(10), 3595-3617.

Hooper, D., Coughlan, J., \& Mullen, M. (2008). Structural equation modelling: Guidelines for determining model fit. Electronic Journal of Business Research Methods, 6(1), 53-60.

Hoşgörür, V., \& Orhan, A. (2017). Okulda zorbalık ve şiddetin nedenleri ve önlenmesinin yönetimi (Muğla Merkez İlçe Örneği). Bayburt Ĕgitim Fakültesi Dergisi, 12(24), 859-880.

Huang, H. (2006). Do print and Web surveys provide the same results? Computers in Human Behavior, 22, 334-350.

Ihaka, R. \& Gentleman, R. (1996). R: A language for data analysis and graphics. Journal of Computational and Graphical Statistics, 5(3), 299-314.

Karacabey, M. F., \& Boyac1, A. (2018). Factors contributing to secondary school dropouts and the dropouts' socioeconomic profiles: Şanlıurfa 
sample. Kuram ve Uygulamada Eğitim Yönetimi, 24(2), 247-293 doi: 10.14527/kuey.2018.007

Karaköse B., \& Bozgeyikli, H. (2012). Örgütsel bağlılık ve çalışma yaşamı kalitesi arasındaki ilişki: Rehberlik araştırma merkezlerinde çalışan personel üzerine bir çalışma. HAK-İŞ Uluslararası Emek ve Toplum Dergisi, 1, 185-202.

Karaköse, T., Yirci, R., \& Kocabaş, I. (2014). A qualitative study of the novice principals' problems in the school management process and solutions. Pakistan Journal of Statistics, 30(6), 1365-1378.

Kayıkçı, K. (2008). Personel hizmetlerinin yönetimi. In R. Sarpkaya (Ed.) Türk Eğitim Sistemi ve Okul Yönetimi (pp. 189-240). Ankara: An1.

Keser, Z., \& Gedikoğlu, T. (2008). Ortaöğretim okul müdürlerinin yetki ve sorumluluklarını kullanma derecelerinin belirlenmesi. Uluslararası Insan Bilimleri Dergisi, 5(2), 1-23.

Köse, A., \& Uzun, M. (2017). Okul öncesi eğitim kurumlarında kadın yönetici olmak: Sorunlar ve eğilimler. Mersin University Journal of the Faculty of Education, 13(3), 1058-1083.

Korkmaz, S., Göksülük, D., \& Zararsız, G. (2014). MVN: An R package for assessing multivariate normality. The R Journal, 6(2), 151-162.

Law, L. Y. S., Walker, A., \& Dimmock, C. (2003). The influence of principals' values on their perception and management of school problems. Journal of Educational Administration, 41(5), 498-523.

Liu, Y., \& Bellibaş, M. Ş. (2018). School factors that are related to school principals' job satisfaction and organizational commitment. International Journal of Educational Research, 90, 119.

Madenoğlu, C. (2013). Eğitim kurumu yöneticilerinin stresle başa çıkma tarzlarının benlik saygısı düzeyleriyle olan ilişkisi. Gümüşhane Üniversitesi Illetişim Fakültesi Elektronik Dergisi, 2(1), 83-105.

Mardia, K. V. (1970). Measures of multivariate skewness and kurtosis with applications. Biometrika, 57(3), 519-530.

Mardia, K. V. (1974). Applications of some measures of multivariate skewness and kurtosis for testing normality and robustness studies. Sankhya, 36,115-128. 
Mindrila, D. (2010). Maximum likelihood (ML) and diagonally weighted least squares (DWLS) estimation procedures: A comparison of estimation bias with ordinal and multivariate non-normal data. International Journal of Digital Society, 1(1), 60-66.

Mpolokeng, T. E. (2011). The effectiveness of financial management in schools in the lejweleputswa education district (Unpublished Master's Thesis). Central University of Technology the School of Teacher Education, Bloemfontein, South Africa.

Nayir, F. (2013). İlköğretim okulu yöneticilerinin örgütsel bağl1lık düzeyi. Illköğretim Online, 12(1), 179-189.

Ok, İ. (2006). İşstresinin ilköğretim okullarında okul yöneticileri üzerindeki etkisi (Konya örneği) (Unpublished Master's Thesis). Selçuk Üniversitesi Sosyal Bilimler Enstitüsü, Konya.

Özdemir, S., \& Sezgin, F. (2002). Etkili okullar ve öğretim liderliği. Kırgızistan Manas Sosyal Bilimler Dergisi, 2(3), 266-282.

Özdoğan Özbal, E. (2017). Okulun ekonomik sorunlarının çözümünde ilkokul müdürlerinin yerel yönetimlerle işbirliği. Journal of Human Sciences, 14(4), 4135-4148.

Özel, E. (2014). Sosyal bilgiler öğretmenlerinin öğretim yaşantılarında okul idaresinden beklentileri. Dumlupınar Üniversitesi Sosyal Bilimler Dergisi, 39, 281-290.

Özer, N., Demirtaş, H., \& Ateş, Ö. F. (2015). Okulların mali durumlarına ve bütçe yönetiminde yaşanan sorunlara ilişkin müdür görüşleri. $e$ International Journal of Educational Research, 6(1), 17-39.

Özgan, H., \& Aydın, Z. (2010). Okul-aile işbirliğine ilişkin yönetici, öğretmen ve veli görüşleri. New World Sciences Academy, 5(3), 1169-1189.

Pamuk, E., \& Kiraz, Z. (2016). Ortaokullarda okutulan seçmeli ders uygulamalarında okul yöneticilerinin karşılaştıkları problemler. Abant İzzet Baysal Üniversitesi Ĕgitim Fakültesi Dergisi, 16(3), 977-1003.

Polat, S., \& Arslan, Y. (2017). School principals' problems in educational environments and their needs for in-service training. 2. International Symposium on New Trends in Social and Liberal Sciences, Barcelona, Spain. 
Porsuk, A., \& Kunt, M. (2012). Denizli merkez ilköğretim okullarındaki okul aile ilişkilerinde karşılaşılan sorunlar üzerine yönetici görüşleri. Pamukkale Üniversitesi Eğitim Fakültesi Dergisi, 31, 203-218.

Revelle, W. (2018) psych: Procedures for Personality and Psychological Research, Northwestern University, Evanston, Illinois, USA.

Rosseel, Y. (2012). Lavaan: An R package for structural equation modeling. Journal of Statistical Software, 48(2), 1-36.

Royston, J. P. (1992). Approximating the Shapiro-Wilk W-Test for nonnormality. Statistics and Computing, 2, 117-119.

Sadık, F., \& Öztürk, H. İ. (2018). Discipline at the school: Examination of school administrators' views about discipline and disciplinary problems. Pegem Ĕgitim ve Öğretim Dergisi, 8(4), 729-770.

Sarpkaya, R. (2006). Eğitim sendikalarından öğretmenlerin beklentileri. Eurasian Journal of Educational Research, 22, 188200.

Selm, M. V. \& Jankowski, N. W. (2006). Conducting online surveys. Quality \& Quantity, 40, 435-456.

Shabahang, M. J., \& Amani, M. (2016). The relationship between personality factors and organizational commitment of Iranian primary school principals. International Journal of Psychology, 3(3), 50-59.

Sincar, M. (2013).Challenges school principals facing in the context of technology leadership. Educational Sciences: Theory and Practice, 13(2), 1273-1284.

Spector, P. E. (1992). Summated rating scale construction. Thousand Oaks, CA: Sage.

Spillane, J. P., \& Lee, L. C. (2014). Novice school principals' sense of ultimate responsibility: Problems of practice in transitioning to the principal's office. Educational Administration Quarterly, 50(3), 431-465.

Strahan, E. J. (1999). Evaluating the use of exploratory factor analysis in psychological research. Psychological Methods, 4(3), 272-299.

Şahin, A. E. (2008). Meslek ve öğretmenlik. In V. Sönmez (Ed.) Ĕgitim Bilimine Giriş (pp. 261-306). Ankara: Anı. 
Şahin, C. (2011). Okul yöneticilerinin yönetici kaygı düzeylerinin çeşitli değişkenlere göre incelenmesi. Ahi Evran Üniversitesi Kırşehir Ĕ̈itim Fakültesi Dergisi, 12(4), 143-161.

Şenel, T., \& Buluç, B. (2016). İlkokullarda okul iklimi ile okul etkililiği arasındaki ilişki. TÜBAV Bilim Dergisi, 9(4), 1-12.

Şentürk, C., \& Sağnak, M. (2012). İlköğretim okulu müdürlerinin liderlik davranışları ile okul iklimi arasındaki ilişki. Türk Eğitim Bilimleri Dergisi, 10(1), 29-43.

Taşdan, M., Tösten, R., Bulut, K., \& Karakaya, V. (2013). Okul yöneticilerinin ilköğretim okullarında karşılaşılan yönetim sorunlarına ilişkin görüşleri. Eğitim Bilimleri ve Uygulama, 12(24), 95-113.

Toker Gökçe, A., \& Acar, E. (2018). School principals' and teachers' problems related to the education of refugee students in Turkey. European Journal of Educational Research, 7(3), 473-484.

Tosun, F. Ç., \& Filiz, T. (2017). Müdür yetkili sınıf öğretmenlerinin karşılaştıkları ekonomik ve okul işletmesiyle ilgili sorunlar. Illkögretim Online, 16(3), 978-991.

Tumwine, D. B. (2014). The role of school managers in managing violence in high schools: A Swaziland case study. Educational Leadership Master Thesis, Pretoria University.

Turan, S., Yıldırım, N., \& Aydoğdu, E. (2012). Okul müdürlerinin kendi görevlerine ilişkin bakış açıları. Pegem Eğitim ve Öğretim Dergisi, 2(3), 63-76.

Ural, A. (2002). Okul müdürlerinin yönetsel stres kaynakları. Abant İzzet Baysal Üniversitesi Eğitim Fakültesi Dergisi, 2(1), 74-84.

Uygun, S. (2005). Türkiye'de geçici öğretmen istihdamı sorunu. XIV. Ulusal Eğitim Bilimleri Kongresi, Pamukkale Üniversitesi Eğitim Fakültesi, Denizli, Kongre Kitab1, 1, 589-596.

Vaske, J. J. (2008). Survey research and analysis: Applications in parks, recreation and human dimensions. State College, PA: Venture.

Vatansever Bayraktar, H., \& Kaya, M. (2017). Okul yöneticilerinin okuldaki disiplin sorunlarıyla ilgili tutumlarının incelenmesi. Journal of Human Sciences, 14(1), 883-901. 
Wise, D. (2015). Emerging challenges facing school principals. Education Leadership Review, 16(2), 103-115.

Wragg, E. C., Haynes, G. S., Wragg, C. M., \& Chamberlin, R. P. (1999). The role of the head teacher (school principal) in addressing the problem of incompetent teachers. Paper presented at the Annual Meeting of the American Educational Research Association (Montreal, Quebec, Canada).

Yıldırım, N. (2011). Okul müdürlerinin motivasyonları üzerine nitel bir inceleme. Abant İzzet Baysal Üniversitesi Eğitim Fakültesi Dergisi, 11(1), 71-85.

Yıldırım, İ., Akan, D., \& Çiftçi, M. (2018). Ortaokul müdürlerine göre okul güvenliğine yönelik tehditler ve çözüm önerileri. Trakya Üniversitesi Sosyal Bilimler Dergisi, 20(2), 135-156.

Yılmaz, A., Bozkurt, Y. \& İzci, F. (2008) Kamu örgütlerinde çalışan kadın işgörenlerin çalışma yaşamlarında karşılaştıkları sorunlar üzerine bir araştırma. Eskişehir Osmangazi Üniversitesi Sosyal Bilimler Dergisi, 9(2), 89-114.

Yunas, M. (2014). Financial management for improving efficiency of schools: Issues and concerns. International Journal of Education and Social Science, 1(1), 49-59.

Kivanc Bozkus is an assistant professor working at Artvin Çoruh University in Turkey. He completed a bachelor's degree in science teaching and worked as a science teacher. By receiving a graduate education grant from the national ministry of education, he got a master's degree in educational leadership. He has got a Ph.D. degree in educational administration. His research interests are professional development of teachers, school development, leadership, and organizational behaviour.

Contact Address: Çayağzı Mah. Artvin Çoruh Üniversitesi Eğitim Fakültesi 08000 Merkez Artvin Turkey

E-mail: kbozkus@gmail.com 


\section{Appendix}

The Problems of School Administrators Scale

\begin{tabular}{|c|c|c|c|c|}
\hline \multicolumn{2}{|c|}{ Items } & M & SD & Dimensions \\
\hline 1 & I think my workload is more than necessary & 3.57 & 1.15 & \multirow{7}{*}{ Workload } \\
\hline 2 & I'm having trouble due to insufficient funding & 4.05 & 1.10 & \\
\hline 3 & I have to take work home & 3.53 & 1.17 & \\
\hline 4 & I also have to work on weekends & 3.16 & 1.27 & \\
\hline 5 & I'm under intense stress & 3.69 & 1.11 & \\
\hline 6 & I feel tired & 3.92 & 1.02 & \\
\hline 7 & Too much paperwork creates trouble & 3.93 & 1.10 & \\
\hline 8 & $\begin{array}{lll}\text { Institutions } & \text { representing } & \text { school } \\
\text { administrators are sufficient in number }\end{array}$ & 3.50 & 1.12 & \multirow{6}{*}{$\begin{array}{l}\text { Personal } \\
\text { rights }\end{array}$} \\
\hline 9 & $\begin{array}{l}\text { Trade unions observe the rights of school } \\
\text { administrators }\end{array}$ & 3.73 & 1.15 & \\
\hline 10 & The ministry observes our rights & 3.51 & 1.20 & \\
\hline 11 & My superiors care about my opinions & 2.63 & 1.18 & \\
\hline 12 & $\begin{array}{l}\text { Legislation solves the problems of school } \\
\text { administrators }\end{array}$ & 3.24 & 1.05 & \\
\hline 13 & Inspections are fair & 3.12 & 1.16 & \\
\hline 14 & I have problems with teachers & 1.84 & 0.90 & \multirow{5}{*}{$\begin{array}{l}\text { School } \\
\text { management }\end{array}$} \\
\hline 15 & I have problems with my manager friends & 1.64 & 0.94 & \\
\hline 16 & $\begin{array}{l}\text { My family obligations prevent me from being } \\
\text { successful in my job }\end{array}$ & 2.05 & 1.12 & \\
\hline 17 & I have health problems & 2.13 & 1.16 & \\
\hline 18 & I find it difficult to get teachers to work & 2.18 & 1.05 & \\
\hline 19 & $\begin{array}{l}\text { The physical facilities of my school are } \\
\text { enough for me }\end{array}$ & 3.53 & 1.28 & \multirow{4}{*}{$\begin{array}{l}\text { School } \\
\text { Climate }\end{array}$} \\
\hline 20 & $\begin{array}{l}\text { School-family cooperation is sufficient at the } \\
\text { school where I work }\end{array}$ & 3.32 & 1.22 & \\
\hline 21 & My students' parents care about education & 3.35 & 1.12 & \\
\hline 22 & $\begin{array}{l}\text { It would be a problem for me to be away from } \\
\text { my hometown }\end{array}$ & 2.17 & 1.41 & \\
\hline
\end{tabular}




\begin{tabular}{|c|c|c|c|c|}
\hline 23 & Students are eager to learn & 3.01 & 1.03 & \\
\hline 24 & $\begin{array}{l}\text { Guidance service offered to students is } \\
\text { sufficient }\end{array}$ & 3.26 & 1.14 & \\
\hline 25 & Society respects me & 2.57 & 1.23 & \multirow{4}{*}{ Respect } \\
\hline 26 & Teachers respect me & 1.87 & 0.88 & \\
\hline 27 & Students respect me & 1.75 & 0.88 & \\
\hline 28 & Parents respect me & 2.11 & 1.05 & \\
\hline 29 & $\begin{array}{l}\text { Political interference in education creates } \\
\text { problems }\end{array}$ & 4.34 & 1.14 & \multirow{11}{*}{$\begin{array}{l}\text { Education } \\
\text { system }\end{array}$} \\
\hline 30 & $\begin{array}{l}\text { Frequent changes in the education system are } \\
\text { problematic }\end{array}$ & 4.32 & 0.98 & \\
\hline 31 & I need qualified teachers at my school & 4.14 & 1.02 & \\
\hline 32 & $\begin{array}{l}\text { I think that rote learning cannot be solved in } \\
\text { the education system. }\end{array}$ & 3.89 & 0.97 & \\
\hline 33 & $\begin{array}{l}\text { Assignment and relocation regulation causes } \\
\text { problems }\end{array}$ & 3.65 & 1.08 & \\
\hline 34 & $\begin{array}{l}\text { There are ideological separation and } \\
\text { favoritism in the education system }\end{array}$ & 3.06 & 1.35 & \\
\hline 35 & $\begin{array}{l}\text { I think the criteria for being a manager should } \\
\text { change. }\end{array}$ & 3.94 & 1.16 & \\
\hline 36 & $\begin{array}{l}\text { There is a big difference between the } \\
\text { facilities of the surrounding schools }\end{array}$ & 3.58 & 1.19 & \\
\hline 37 & $\begin{array}{l}\text { There are difficulties in ensuring academic } \\
\text { success }\end{array}$ & 3.37 & 1.02 & \\
\hline 38 & Negative student behavior creates problems & 3.97 & 1.05 & \\
\hline 39 & Immigrant students create problems & 3.33 & 1.37 & \\
\hline 40 & I wish I could do additional work & 3.51 & 1.41 & \multirow{2}{*}{$\begin{array}{l}\text { Organizational } \\
\text { commitment }\end{array}$} \\
\hline 41 & $\begin{array}{l}\text { I would like to work in another job if I get the } \\
\text { opportunity }\end{array}$ & 2.79 & 1.45 & \\
\hline 42 & I am exposed to verbal violence at my school & 1.80 & 1.12 & \multirow{3}{*}{ Violence } \\
\hline 43 & $\begin{array}{l}\text { I am exposed to physical violence at my } \\
\text { school }\end{array}$ & 1.34 & 0.82 & \\
\hline 44 & Mobbing is applied against me & 1.57 & 1.01 & \\
\hline
\end{tabular}

